\title{
Response of Nesting Lapland Longspurs (Calcarius lapponicus) to Burned Tundra on the Seward Peninsula
}

\author{
JOHN M. WRIGHT
}

\begin{abstract}
The response of breeding Lapland longspurs to burned sedge tussock-shrub tundra was studied in 1978 on the Seward Peninsula in an area burned by lightning-ignited fires during 1977. In late May and mid-June 1978, plant standing crop in burned tundra was $<5 \%$ of standing crop in unburned tundra. Lapland longspurs were less abundant in burned than in unburned tundra. An average of 1.4 longspurs $\mathrm{h}^{-1}$ were recorded in burned tundra, whereas 4.6 longspurs $\mathrm{h}^{-1}$ were seen in unburned tundra. One longspur nest was found in 5 ha of burned tundra; three were found in 5 ha of unburned tundra. Nest locations in burned and unburned tundra were similar though nests in burned tundra generally had less protective cover. Several factors may be involved in the reduced abundance of Lapland longspurs in burned tundra.
\end{abstract}

Key words: Lapland longspur, burned tundra, Alaska, abundance, nest sites

RÉSUMÉ. La réaction de bruants lapons en saison des nids envers la toundra de laîches élevées incendiée fut étudiée en 1978 sur la péninsule de Seward, dans une région incendiée par l'éclair en 1977. Entre la fin-mai et la mi-juin 1978, les plantes sur pied dans la toundra brûlée étaient inférieures en nombre de $5 \%$ à celles dans la toundra non brûlée. Les bruants lapons étaient moins nombreux dans la toundra brulée que dans la toundra non brûlée. Une moyenne de 1.4 bruant par $\mathrm{h}^{-1}$ a été enregistrée dans la toundra brúlée, tandis que 4.6 bruants par $\mathrm{h}^{-1}$ ont été discernés dans la toundra vierge. Un nid de bruant a été trouvé dans 5 ha de toundra brûlée: trois ont été trouvés dans 5 ha de toundra non bralée. L'emplacement des nids variait peu entre la toundra brûlée et non brûlée, bien que les nids dans la toundra brûlée étaient généralement moins recouverts de matières protectrices. Plusieurs facteurs sont peut-être en jeu dans la présence moins marquée de bruants lapons dans la toundra incendiée.

Mots clés: bruant lapon, toundra incendiée, Alaska, abondance, emplacement de nids

Traduit par Maurice Guibord, Department of Archaeology, University of Calgary.

\begin{abstract}
PEзоме. Отнопение гнездящихся лапландских подорожников к соженным пучкам тундровой осоки было изучено в 1978 Г. на полуострове Суерд, где тундра была соххена молнией в $1977 \mathrm{\Gamma}$. В позднем мае и в середине июня, масса растительного насахдения в соженной тундре была 5 массы насатдения в несохтенной тундре. Јапландские подорожнии были менее обильные

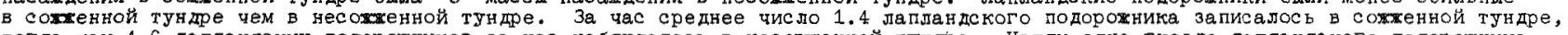
тогда как 4.6 лапландских подорохников за час наблюдалось в несохтенной тундое. Напли одно Гнездо лапландского подорожника з 5 гектарах сохтенной тундр; три нашли в 5 гектарах несоженной тундры. Не было очевидных разниц в фенологии Гнездовой деятельности мехду соххеннй и несохтенной тундрой, а размещения гнезд были похохие друг на друга, хотя гнезда в соххенной тундре вообще имели меньще защитного насахдения. обсухдаются несколькие факторы, которые мовет быть относятся к уменьшитенному обилив лапландского подорохника в соженной тундре.
\end{abstract}

Translated by Charles H. Welling, LGL Alaska Research Associates, Inc.

\section{INTRODUCTION}

Fires burned vast areas of tundra vegetation in northwestern Alaska during the summer of 1977. The occurrence of these fires, and earlier fires near Inuvik, Northwest Territories, has attracted attention to the effects of fire on tundra ecosystems. Most investigations have focused on the effects of tundra fire on vegetation (e.g. Wein and Bliss, 1973; Hall et al., 1978; Racine, 1981); its effects on animals remain unreported. This preliminary study compares aspects of the nesting ecology of Lapland longspurs (Calcarius lapponicus) in burned and unburned tundra in the year following a fire.

The Lapland longspur (Fig. 1) is one of the most widespread and consistently abundant terrestrial vertebrates in the Arctic and Subarctic (Williamson, 1968). Longspurs are the dominant nesting bird within sedge tussock-shrub tundra (Williamson et al., 1966; Wright, 1979; plant community name from Viereck and Dyrness, 1980), which covers more area than any other plant community in northwestern Alaska (Hanson, 1953). Sedge tussock-shrub

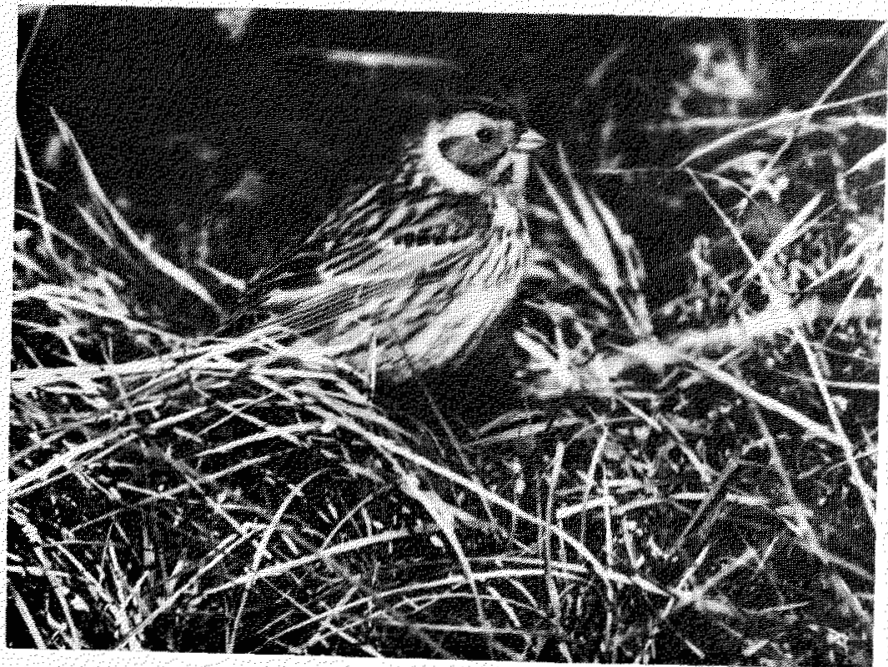

FIG. 1. Female adult Lapland longspur (Photo, Susan Hills).

tundra was one of the most frequently burned plant communities during the 1977 fires on the Seward Peninsula (Racine, 1979).

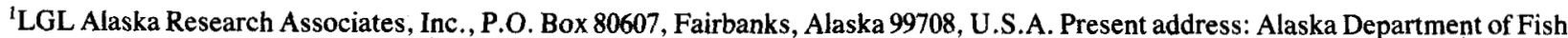
and Game, P.O. Box 199, Dillingham, Alaska 99576, U.S.A. 
TABLE 1. Frequency of occurrence and standing crop ${ }^{a}$ of vascular plants in burned and unburned sedge tussock-shrub tundra, Inmachuk River, northern Seward Peninsula, 1978 (fire occurred between July and September 1977)

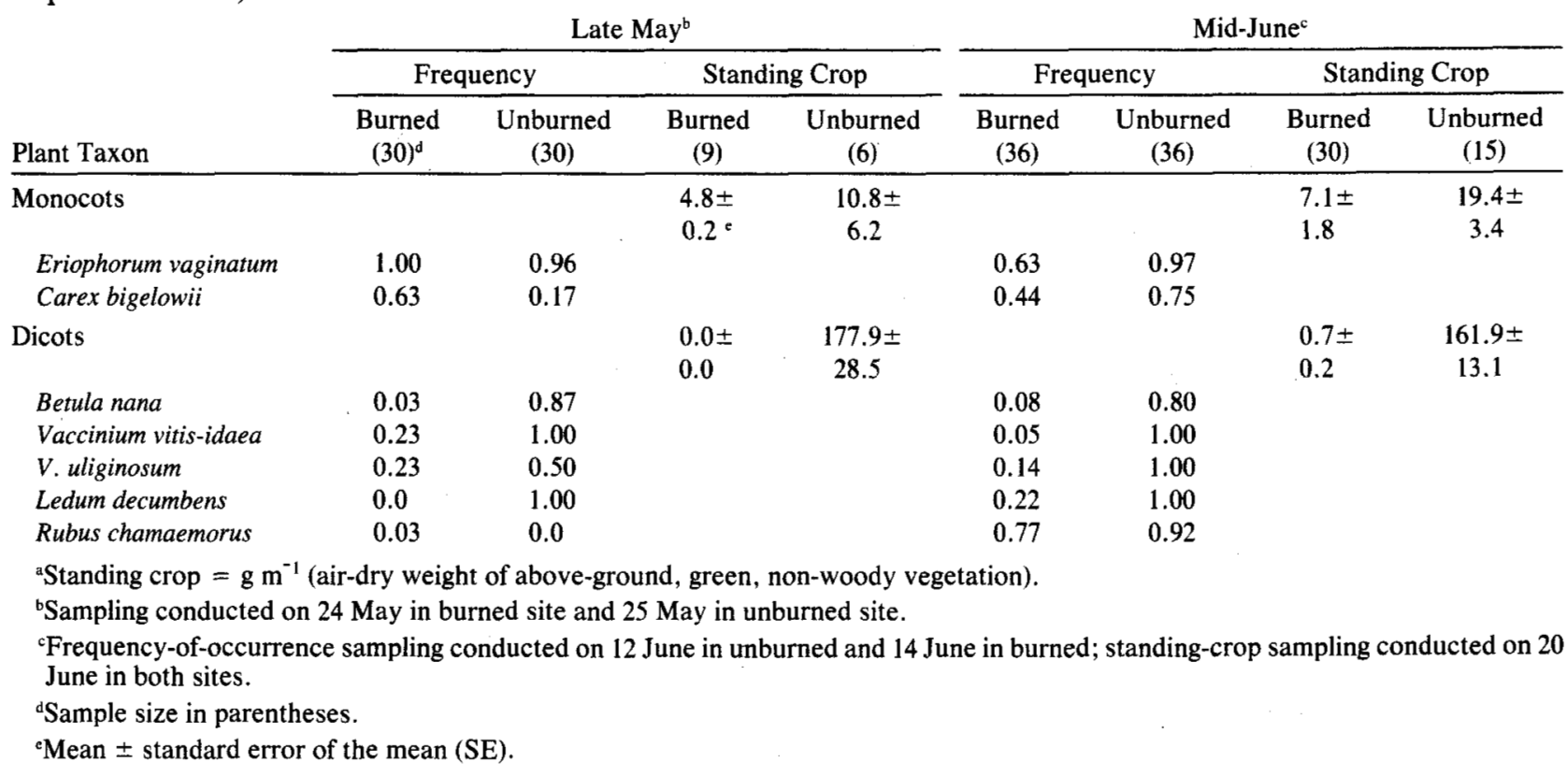

\section{STUDY AREA}

This study was centered at the Utica Creek landing strip $\left(65^{\circ} 55^{\prime} \mathrm{N}, 163^{\circ} 00^{\prime} \mathrm{W}\right)$ near the Inmachuk River, $22 \mathrm{~km} \mathrm{SSE}$ of Deering, Alaska (Fig. 2). A lightning-caused fire burned approximately $1000 \mathrm{~km}^{2}$ just east of the Inmachuk River between 9 July and 12 September 1977 . I selected two study sites within sedge tussock-shrub tundra, one burned and one unburned, $5 \mathrm{~km}$ apart on opposite sides of the Inmachuk River. The two sites were similar in topography, and it was assumed that they were vegetatively similar prior to the 1977 fire. The climate, terrain and vegetation of the area are described by Racine (1981).

\section{METHODS AND RESULTS}

In May and June 1978, the frequency of occurrence and the non-woody standing crop of vascular plants were measured in the burned and unburned sites. Frequency of occurrence was noted in randomly selected $33 \times 100 \mathrm{~cm}$ plots (sampling dates and sample sizes in Table 1). Aboveground, green, non-woody vegetation (i.e. standing crop) was clipped from randomly selected $25 \times 50 \mathrm{~cm}$ plots (Table 1).

Within the burned site, the 1977 fire consumed nearly all above-ground vegetation, except for the cores of sedge tussocks and scattered small patches of moss, and much of the organic layer of the soil. From late May through midJune 1978, tussock-forming sedges (cottongrass, Eriophorum vaginatum, and Bigelow's sedge, Carex bigelowii) were the most common living plants in the burned site, and their

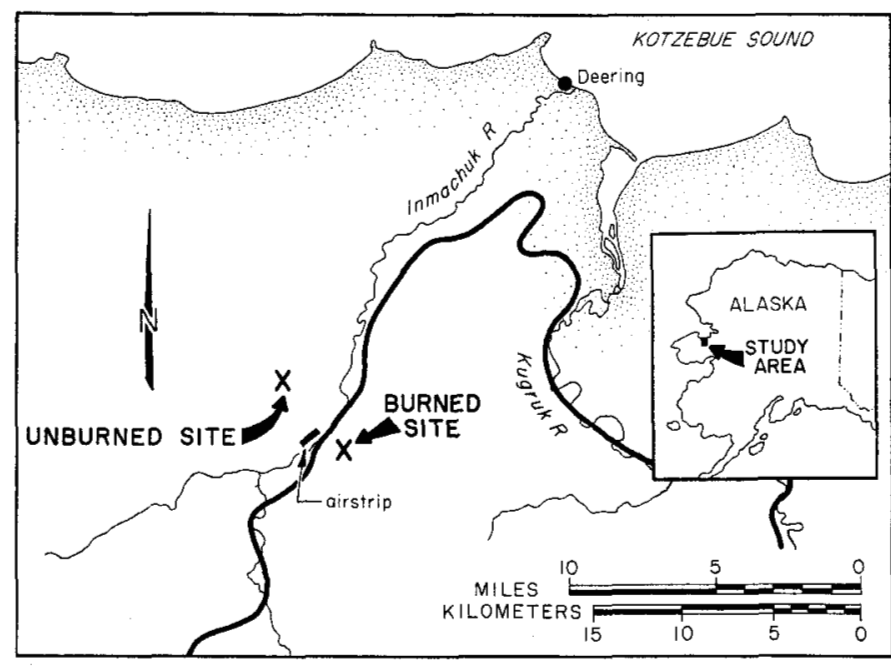

FIG. 2. Location of the study sites on the northern Seward Peninsula, Alaska. The bold line represents the approximate boundary of the 1977 tundra fire.

growth accounted for more than $90 \%$ of the vascular plant standing crop (Table 1). Cloudberry (Rubus chamaemorus) accounted for most of the limited standing crop of dicotyledonous plants in the burned site in mid-June. Through out the study, the standing crop in the burned site equalled less than $5 \%$ of the standing crop in the unburned site (Table 1). Within the unburned site, dicots accounted for approximately $90 \%$ of the standing crop of vascular plants. In addition to this great difference in green plant material, standing dead sedge leaves and woody stems of shrubs were present in substantial amounts only in the unburned site. 
To measure Lapland longspur abundance, four $25 \mathrm{x}$ $100 \mathrm{~m}$ strip transects (a total of $5 \mathrm{ha}$ ) were randomly selected in each site. Each set of strip transects was searched three times between 1 and 8 June 1978, when most breeding longspurs were incubating or caring for young nestlings. The strip transect sampling method is discussed in detail by Conner and Dickson (1980). An abundance index, birds seen on the ground per hour, was calculated for each transect search. During the initial transect searches, conducted on 1 and 2 June, $1.8 \pm 0.8$ (mean of 4 transects \pm standard error of the mean) longspurs were seen per hour in the burn and $5.9 \pm 1.4$ were seen in the unburned site. Abundance indices for the second ( 6 June) and third ( 8 June) transect searches were $1.3 \pm 0.9$ in burned $v s .3 .0 \pm$ 1.2 in unburned, and $1.2 \pm 0.8$ in burned vs. $5.6 \pm 2.5$ in unburned, respectively. Overall, an average of 1.4 Lapland longspurs was seen each hour in the burned site, and 4.6 were seen each hour in the unburned site.

One Lapland longspur nest was found within the strip transects in burned sedge tussock-shrub tundra, equalling a density of 1 nest per 5 ha (or 20 nests $\mathrm{km}^{-1}$ ). Three longspur nests were located within the strip transects in unburned sedge tussock-shrub tundra ( 3 nests per 5 ha, or 60 nests $\mathrm{km}^{-1}$ ). One nest was also discovered adjacent to the transects in the burned site, and three nests were found just off-transect in the unburned site. All of the nests found on-transect and all but one nest off-transect were located during the first search; subsequent searches led to the discovery of only one nest off-transect. It is therefore unlikely that any longspur nests were missed on-transect.

The nest sites selected by Lapland longspurs in burned sedge tussock-shrub tundra were similar to those used in unburned tundra. All three nests found in burned tundra were built against the sides of charred sedge tussocks. In unburned sedge tussock-shrub tundra, five of eight nests were built in the sides of tussocks, two were placed between tussocks, and one was not associated with tussocks. At other sites on the northern Seward Peninsula, 14 of 18 nests in unburned sedge tussock-shrub tundra were built in the sides of sedge tussocks (Wright, unpublished). In both burned and unburned tundra, monocots (including

TABLE 2. Plant cover, including live and dead vegetation, within $15 \mathrm{~cm}$ radius of Lapland longspur nests in burned and unburned sedge tussock-shrub tundra, Inmachuk River, northern Seward Peninsula, 1978

\begin{tabular}{lcc} 
& \multicolumn{2}{c}{ Percent Cover $(\overline{\mathrm{x}} \pm \mathrm{SE})$} \\
\cline { 2 - 3 } Plant Group & Burned $(\mathrm{n}=3)$ & Unburned $(\mathrm{n}=8)$ \\
\hline Lichens & $3.3 \pm 1.7$ & $3.1 \pm 0.9$ \\
Mosses & $11.6 \pm 6.6$ & $3.1 \pm 0.9$ \\
Monocots $^{\mathrm{a}}$ & $45.0 \pm 10.0$ & $48.1 \pm 7.1$ \\
Deciduous shrubs $^{\mathrm{b}}$ & $3.3 \pm 1.7$ & $28.1 \pm 7.2$ \\
Evergreen shrubs $^{\mathrm{c}}$ & $3.3 \pm 1.7$ & $15.0 \pm 4.5$ \\
$\quad{ }^{a}$ Primarily Eriophorum vaginatum and Carex bigelowii. \\
$\quad$ 'Primarily Betula nana and Vaccinium uliginosum. \\
\multicolumn{2}{l}{ 'Primarily Vaccinium vitis-idaea and Ledum decumbens. }
\end{tabular}

dead as well as live vegetation) covered just under half of the area within $15 \mathrm{~cm}$ of nests (Table 2). However, nests in burned tundra tended to be more exposed because of the nearly complete absence of evergreen and deciduous shrubs following the fire. All nests observed consisted of dry sedge leaves and ptarmigan (Lagopus spp.) feathers.

Assuming that pre-burn populations of longspurs on the two study sites were similar, these data suggest that the abundance of breeding Lapland longspurs was reduced in burned sedge tussock-shrub tundra in the year following a fire. The following factors and mechanisms may have been involved:

1) Burning deterred settling. Most birds apparently select habitats on the basis of proximate factors such as landscape, terrain and vegetation structure (Hilden, 1965; James, 1971). In temperate regions, the abundance of sparrows declined immediately following fires in grasslands and only recovered after vegetative regrowth provided suitable cover (Vogl, 1973). In contrast, during a study of habitat selection by birds following a prescribed fire in a young pine forest, Emlen (1970) found essentially no response to burning and suggested that individual attachments to home ranges transcended species characteristic habitat responses.

2) Burning caused males to establish larger breeding territories. In arctic Alaska, the size of breeding territories of Lapland longspurs is related to the habitat composition of the area (Seastedt and MacLean, 1979). Males may have established larger territories in the burned site if burned sedge tussock-shrub tundra was perceived as unproductive habitat.

3) Burning reduced prey abundance. If sufficient food was not available in burned tundra, longspurs may have abandoned breeding territories.

4) Burning eliminated nest sites. Charred tussocks apparently were acceptable sites for some longspurs, but the fires likely reduced the quality of nest sites by removing shrub cover.

Clearly, further study is necessary to confirm the results of this preliminary investigation and to clarify which factors and mechanisms are involved in the response of Lapland longspurs to burned tundra. In addition to answering the specific question of how one species responds to the burning of its nesting habitat, studies on longspurs in burned tundra would increase our understanding of habitat selection by birds and the relationship of resource abundance to territory size.

\section{ACKNOWLEDGEMENTS}

Funding for field work was provided under a contract with the U.S. Fish and Wildlife and National Park services to the Alaska Cooperative Wildlife Research Unit and D. R. Klein. I thank J.D. Levison for assistance in the field; S. G. Fancy, S. R. 
Johnson, S. F. MacLean, Jr., D. M. Troy and M. R. Lein for their constructive comments on an earlier draft of the manuscript; P. D. Hollingdale for drafting the figure; and E. M. Kimbrough for typing the manuscript.

\section{REFERENCES}

CONNER, R.N. and DICKSON, J.G. 1980. Strip transect sampling and analysis for avian habitat studies. Wildlife Society Bulletin 8:4-10.

EMLEN, J.T. 1970. Habitat selection by birds following a forest fire. Ecology 51:343-345.

HALL, D., BROWN, J. and JOHNSON, L. 1978. The 1977 tundra fire in the Kokolik River area of Alaska. Arctic 31:54-58.

HANSON, H.C. 1953. Vegetation types in northwestern Alaska and comparisons with communities in other arctic regions. Ecology 34:111-140.

HILDEN, O. 1965. Habitat selection in birds: A review. Annales Zoologica Fennica 2:53-75.

JAMES, F.C. 1971. Ordinations of habitat relationships among breeding birds. Wilson Bulletin 83:215-236.

RACINE, C.H. 1979. The 1977 tundra fires in the Seward Peninsula, Alaska: Effects and initial revegetation. BLM-Alaska Technical Report 4. Anchorage, AK: U.S. Department of the Interior, Bureau of Land Management, Alaska State Office.
1981. Tundra fire effects on soils and three plant communities along a hill-slope gradient in the Seward Peninsula, Alaska. Arctic 34:71-84.

SEASTEDT, T.R. and MacLEAN, S.F. 1979. Territory size and composition in relation to resource abundance in Lapland longspurs breeding in arctic Alaska. Auk 96:131-142.

VIERECK, L.A. and DYRNESS, C.T. 1980. A preliminary classification sytem for vegetation of Alaska. General Technical Report PNW-106. Portland, OR: U.S. Forest Service, Pacific Northwest Forest and Range Experiment Station.

VOGL, R.J. 1973. Effects of fire on the plants and animals of a Florida wetland. American Midland Naturalist 89:334-347.

WEIN, R.W. and BLISS, L.C. 1973. Changes in arctic Eriophorum tussock communities following fire. Ecology 54:845-852.

WILLIAMSON, F.S.L. 1968. Alaska Longspur. In: Austin, O.L. Jr. (ed.). Life History of North American Cardinals, Grosbeaks, Buntings, Towhees, Finches, Sparrows and Allies. U.S. National Museum Bulletin 237, Part 3:1608-1627.

, THOMPSON, M.C. and HINES, J.Q. 1966. Avifaunal investigations. In: Wilimovsky, N.J. and Wolfe, J.N. (eds.). Environment of the Cape Thompson region, Alaska. Oak Ridge, TN: Atomic Energy Commission, Division of Technical Information. 437-480.

WRIGHT, J.M. 1979. Reindeer grazing in relation to bird nesting on the northern Seward Peninsula. Unpublished M.S. thesis, Alaska Cooperative Wildlife Research Unit, University of Alaska, Fairbanks, AK 99701. 